\title{
Measuring Religiosity in Consumer Research from Islamic Perspective
}

\author{
Dr. Hamza Khraim \\ Faculty of Business, Middle East University \\ P.O.Box 383, Amman 11831, Jordan \\ E-mail: hkhraim@meu.edu.jo
}

\begin{abstract}
In a constantly changing and increasingly globalized world, the construct of culture and subculture have become increasingly central to the consumer behavior literature. Religion still plays a significant role in influencing social and consumer behavior. This paper will shed some light on measuring religiosity fom Islamic perspective. All possible alternatives within different dimensions were assessed to find out the most suitable combination of dimensions that gives the best results in measuring Islamic religiosity. Seven Factors were extracted by factor analysis form the four dimensions. The findings of the study indicated that the combination of three dimensions namely (Current Islamic issues, religious education, and sensitive products) produce the best results among other dimensions.
\end{abstract}

Keywords: Religiosity, Consumer research, Consumer behavior, Islamic religiosity

\section{Introduction}

Religion is an element of culture that pervades every aspect of a society and permeates the life of individuals whether one is a believer or a non-believer. Cultural dimensions are very dynamic in a society, but religious tenets form a stable and static pillar in the society. Once the fundamentals of a religion have been grasped, the global marketer can be assured they will not be changing all too frequently. Religion is not a fad that can be dismissed by the marketer as a short-term change, but rather it is a long-term phenomenon, therefore it is considered a valuable construct in understanding consumers (Kim et al., 2004). Religion is an important cultural factor to study because it is one of the most universal and influential social institutions that has significant influence on people's attitudes, values and behaviors at both the individual and societal levels.

Whether working directly through taboos and obligation or through its influence on the culture and society, religious values and beliefs are known to affect ritualistically and symbolically human behavior. Religion and its associated practices often plays a pivotal role in influencing many of the important life transitions that people experience (e.g. births, marriages and funeral rites), in values that come to be important to them (e.g. moral values of right and wrong),in shaping public opinion on social issues (e.g. cohabitation, premarital sex, family planning, organ donation, and the like), in what is allowed and forbidden for consumption (e.g. restriction on eating and drinking) and in many other aspects that pertain to everyday life. These norms however vary between different religious faiths and the degree of observance determine to what extent these norms are kept.

Differences in religious affiliations tend to influence the way people live, the choices they make, what they eat and whom they associate with. It would seem that obtaining an in-depth understanding of the dominant religion and its effect on consumer behavior would be essential to an intimate understanding consumer choice in a particular context. Religious belief is a significant factor in influencing consumption behavior because by the rules and taboos it inspires. Furthermore, religiosity represents an inherent human value which tends stable over a fairly long period of time, and finally, many elements of religiosity are observable, and therefore of pragmatic value to marketers. Religion also represents a potentially significant element in many, if not all, the problem-solving and decision-making phases. For example, research in religious attribution theory suggests, that religion may affect how one understands the meaning of many problems (Delener, 1994). Stark and Finke (2002) maintain that religious economies provide niches that satisfy consumer demand for religious products. To the extent that the religious market place is deregulated, the cost of and barriers to participation will be low. This enables religious suppliers to provide a more comprehensive array of services. New products will continue to be offered until the religious market is sufficiently penetrated and reaches a saturation point.

Hirschman (1983) ventured three possible reasons to explain why religion per se has not been adequately examined in the consumer behavior literature. The first reason for the slow development of literature in this area is the possibility that consumer researchers are unaware of the possible links between religion and consumption patterns. The second reason is a perceived prejudice against "religion" within the research community; once 
being a "taboo" subject and too sensitive to be submitted for investigation, (i.e. the potential for inadvertent offence and the legal protection afforded freedom of religion). Finally, she claims that religion is everywhere in our life and therefore may have been overlooked by researchers as an obvious variable for investigation in the field. Although Hirschman made this assertion some years ago, it is still true today. To date, few studies have investigated religion as a predictor of consumption patterns even though there have been calls for such research in the literature. An analysis conducted by Cutler (1991) that examined the frequency with which papers on religion were published in the academic marketing literature from 1956 to 1989 found that only thirty five articles had a religious focus with nearly $80 \%$ of these articles published in the 1980 s. Of these, only six were specifically identified as articles within the consumer behavior discipline.

From the above, it's obvious that the role of religion as a variable in consumer behavior models is still not well established. The reason behind this absence could be attributed to the problem of how to measure religiosity. The purpose of this study is to evaluate the different methods used in measuring religiosity and to propose a new construct for measuring religiosity in Islamic context. The study aims to contribute to our current stock of understanding of this relationship as well as to provide a basis for further investigation in this promising research area. It is hoped that research will fill in the gap about how to measure this important variable.

\section{Research Objectives}

The main objectives of this research are to:

- Review previous attempts in measuring religiosity and the application of such measures in consumer behavior research; and

- Provide alternative measurement for Islamic religiosity in the context of Muslim environment.

The conceptualization and measurement of religious constructs have been key issues in the field of sociology. Traditionally religiosity has been conceptualized as a unidimensional construct with church attendance and denomination being the primary measure (Bergan, 2001). Though this unitary measure may be simple at the cost of validity and remains a frequently used measure within the literature (Schwartz \& Huismans, 1995), many researchers argued that frequent use does not make such a unidimensional assessment an acceptable research practice. As Bergan (2001) very aptly pointed out, the reliance on religious attendance as a sole measure of religiosity may be insufficient and lead to incorrect conclusions. In fact, the unidimensional view of the nature of religiosity gives rise to one major concern that relates to the difficulty in equating greater attendance of worship in congregation and increased religious commitment. A person may attend prayers in congregation for several reasons, for example, to avoid social isolation, to please their colleagues, or it can be a form of prestigious action to dominate over others. Thus we cannot say that those who are high in religious practice are high in religiosity because this practice could be a routine action more than devotional.

Throughout the 1960s, considerable empirical efforts were made to refine the conceptualization of religiosity and produce valid multidimensional measures (Golden, 1960; Fukuyama, 1961; Lenski, 1961; Glock and Starck, 1966; Faulkner and DeJong, 1966; Gorlow and Schroede, 1968; Stark and Glock, 1968; King and Hunt, 1969). The recognition of the multidimensional nature of religiosity allows for a more thorough understanding of the potential importance of different dimensions or forms of religiosity. Research conducted in the area of psychology has successfully produced a plethora of scales to measure a wide variety of religious phenomena including attitudes, beliefs and values (Hill \& Hood, 1999). Most research has focused upon indices of intrinsic (religion as an end), extrinsic (religion as a means) and quest (religion as a search) dimensions of religiosity. However, there is no consensus among experts as to the number of dimensions that make up the religiosity construct. Religiosity is an intricate concept and a variegated human phenomenon, and seems to cover considerable ground such as behaviors, attitudes, beliefs, feelings and experiences. Religious scholars and sociologists do not agree on whether adequate measures of individual religiosity can be developed and therefore such measures are subjectively devised by researchers to fit their research objectives. Thus, the content and number of religious dimensions vary considerably and may depend on the nature of the research, purpose and context.

Johnstone (1975) summarizes the different approaches that are used in the measurement of religion. He classifies them into three approaches:

1) The Organizational Approach. This approach includes;

- The member/nonmember dichotomy

- Major religious families 
- Denominational affiliation

2) The Individual Approach. This approach includes

- Measures of individual ritual participation

- Measures of individual prayer life

- Measures of importance of religion to individuals

3) Multidimensional measures. This includes using all the different dimensions which may be used in the measurement of religion, because there are many ways to "be religious" and therefore much too complex to measured in only one way.

So, the dimensionality of religion is considered as an unresolved problem. Religion is a complex and variegated human phenomenon, and seems to cover considerable ground: behaviors, attitudes, values, beliefs, feelings, experiences. Some researcher's implicity suggests it is unidimensional by using single measure. Others use multidimensional measures. The "resolution" writes Gorsuch (1984) "could be both/and rather than either/or" (p.232). Bergin (1991, p.31) states that "one finding that most scholars in this area agree on is that religious phenomena are multidimensional."

\section{Measures of Religiosity in Consumer Behavior Research}

The first attempt to study the influence of religion on consumer behavior was undertaken by Allport and Ross (1967) who developed the intrinsic-extrinsic Religious Orientation Scale (ROS) based on Allports theoretical attempts, dating back to 1950 to measure intrinsic-extrinsic religiousness. The scale was designed to measure religiosity in consumer research by operationalizing the construct either as a means to reach self-centered ends or as an end in itself. While the ROS has proven to have acceptable reliability and has shown some indication of applicability for marketing in general and consumer research in particular (Delener \& Schiffman, 1988; Delener, 1990a,1990b, 1994; Essoo \& Dibb, 2004), one serious shortcoming of the inventory is that they were specifically designed for use with Christian or Judeo-Christian subjects. Thus, direct adaptation of the scale is not always feasible and valid to measure the degree of religiosity of other than Judeo-Christian religions, although the scale has been used in one study involving Muslim and Hindu subjects in Mauritius (Essoo \& Dibb, 2004). Genia (1993), as a result of his psychometric evaluation of the ROS, recommends that the item measuring frequency of worship attendance be dropped, because it presents theoretical as well as methodological problems (p. 287). In measuring Islamic religiosity, for instance, this item applies only to men because they are obligated to attend worship in congregation at mosque at least once a week on Friday. The intrinsic items on the scale have also been shown to lack internal consistency and to be of questionable value for other than Christian religions (e.g. Genia, 1993).

Hirschman (1983) used religious affiliation as opposed to religiosity in studying the consumer consumption process. She argued that religious affiliation influence (1) personality structure (2) fertility and sexual mores (3) political views, and (4) socio-economic status. Hirschman investigated the differences in the religious affiliation of Catholic, Protestant, and the Jews with respect to four consumption domains: (1) entertainment, (2) transportation, (3) housing, and (4) family pets. The empirical data presented suggest that religious affiliation serve as an important tool to study several consumer behaviors constructs.

Wilkes et al., (1986) studied the role of religiosity in shaping the lifestyles of the consumers. Four items were used in this study to assess religiosity: 1) church attendance; 2) importance of religious values; 3 ) confidence of religious values; and 4) self-perceived religiousness. Findings show that consumers with greater religious commitment were less likely to use credit and more likely to prefer national brands of products. The findings show that religiosity is a viable consumer behavior construct because it (1) did correlate with the lifestyle variables selected; (2) contributed directly to the model along with gender, age, and income; and (3) was successfully operationlized through multiple measures.

Delener (1990) examines the effect of religion and religious orientation possessed by Catholic and Jewish families on one aspect of marketing namely, the perceived risk in durable goods purchase decisions. The result shows that Catholic consumers were more sensitive to any potential negative consequences of their purchase decisions. The findings further suggest that religion and religious orientation should be viewed as variables having great potential influences on consumption. McDaniel and Burnett (1990) investigated various aspects of the relationship between consumer religiosity and retail store evaluative criteria held by consumers. In this study religiosity was viewed from two perspectives; Religious commitment and religious affiliation. The results of this study show that one aspect of religiosity, religious commitment particularly measured by cognitive religiosity and one aspect of behavioral religiosity -church attendance- is significant in predicting the importance 
individuals place on certain retail evaluative criteria.

Sood and Nasu (1995) studied the significance of religion in explaining the consumer shopping behavior. This study was done among the American Protestant and Japanese consumers and how different religions and level of religiosity influence the consumer shopping behavior. The findings of the study suggested that there is no difference in consumer shopping behavior between the devout and casually religious Japanese. This could be attributed to the fact that religion is not an important element in the overall Japanese culture. While on the other hand, the study found that there was a difference between devout and casually American Protestant consumer shopping behavior.

The aim of Kim et al., (2004) research was to examine whether religion and intensity of religious belief has an effect on the attitudes towards the advertising of controversial products. Four religious groups (Buddhism, Christianity, Islam and non-religious believers) and four controversial product groups (gender/sex related products, social/political groups, health and care products, and addictive products) were created. Among the results it was found that there is a significant difference between the four controversial product groups and the four religious denominations. Evidently, the Islamic followers found the advertising of gender/sex related products, social/political groups, and health and care products most offensive relative to the other three religions. In addition, the religiously devout respondents were more likely to find advertising of gender/sex related products, health and care products, and addictive products more offensive than the less devout followers.

Mokhlis (2009) study seeks to examine the influence of religiosity on one aspect of consumer behavior shopping orientation. The research aims to understand the relevancy of religiosity on consumer behavior across different cultural settings, namely Islam, Buddhism, Hinduism and Christianity. The researcher used both religious affiliation and religious commitment to measure religiosity. The findings revealed that the differences between consumer behavior in general were much more overt for religiosity than merely for religious affiliation. This implies that religiosity may serve as a potentially powerful predictor and determinant of consumer behavior. The summary of previous studies is presented in Table1.

\section{MEASURING RELIGIOSITY IN ISLAMIC COMMUNITY}

Most of the empirical studies trying to stipulate the components of religiosity have been within one culture, the United States; and are confined to the Christian community. Although some of the existing religiosity scales used for Christians may contain some concepts and items that could be applicable to Muslims, but as a whole, these scales are culture-bound and unsuitable for measuring religiosity among Muslims. McFarland (1984) contend that "Scales specific to Christianity are useless in studying psychological aspects of Islam, for example.... To develop a measurement of religion with universal application, we clearly must move beyond our excessive focus on American Christianity.

Recently Muslim population has become, to a limited degree, a target for psychological research in the area of religion. Most of the researchers tried to discover the best approach and tools in measuring Islamic religiosity. The scale developed by Taai (1985) is a scale driven from a theological Islamic teaching sources. Taai used belief and practice dimensions to measure Islamic religiosity. In measuring practice and belief, Taai did not differentiate between what is recommended and what is obligatory. For example, in practice dimension, Taai mix together prayer performance, fasting Rammadan, which are obligatory duties and a Muslim has no choice but to do them, with practices like seeking knowledge and voluntary prayer. This can lead us to bias results, since recommended practices in Islam are optional, and the Muslim have the choice to leave it if he can not do it.

Albehairi and Demerdash (1988) scale was developed to measure intrinsic and extrinsic [ I and E] religious orientation among Muslims. Among the 34 items used in this study, 20 items were adopted form Allport and Ross (1967) Intrinsic - Extrinsic Religious Orientation Scale, with very slight rewording in some items which might be due to translation. Form this perspective we assume that these items used by Albehairi and Demerdash to measure the intrinsic - extrinsic Islamic religiosity does not reflect the real content of Islamic religion, since Islamic teachings are different from other religions, for example in measuring Islamic religiosity, Genia (1993), recommends that the item measuring frequency of worship attendance be dropped, because this item applies only to men, in addition to the lack of internal consistency pertains to the intrinsic items. Due to those limitations, replicating these items in measuring Islamic religiosity considered as inappropriate.

In his attempt to measure Islamic religiosity, Alsanie (1989) draws on the basic Islamic view which combines faith with deeds (or belief with action). According to this view, Alsanie treated belief and practice in has scale as unidimensional, with the one dimension being general religiosity. Alsanie treatment of religion as a general concept, considering his view, may not be warranted. Although belief and behavior, in the Islamic faith, are supposed to be concurrent in people's every day lives, they are not necessarily inseparable. In other words, a 
person could have good faith and strong belief in the religion but not act upon that belief or practice it. On the other hand, a person could be faithfully practicing what he believes in, but his belief might not be in accordance with the teachings of the religion. So belief and practice, which is considered a result of belief, are viewed jointly in the Islamic religious system as an indication of good religiosity. But the two are not the same and, thus, cannot be measured as one component, as Alsanie did.

Albelaikhi (1997) used three dimensions to measure Islamic religiosity. Like Taai (1985) Albelaikhi used the belief and practice dimensions, but he did not include the scores on the basic elements of belief measures with the rest of other measure he use as Taai did. This rises the question of the usefulness of including such dimension. The attitude dimension was about having positive attitude towards God (Allah), his messengers, and his religion in general. This dimension is more related to belief dimension, and those who considered as believers must have a positive attitude towards God, his messengers, and religion in general. That means practice is the only dimension which can used in this study. Moreover, Albelikhi found many difficulties in interpreting and labelling some components as well as, the items he used failed to represent the identified dimensions. With the lack of attention on practical behavior, this study shows that it will very troublesome to create a good measurement of Islamic religiosity. The measures religiosity used by these authors are summarised in Table 2 .

\section{Challenges in Measuring Islamic Religiosity}

It will be more appropriate to highlight some of the potential problems that we will encounter in measuring Islamic religiosity before we discuss our attempt. It should be noted that these problems are not necessarily unique to Islam or to Islamic societies. Some of the potential problems are discussed below:

\section{Measuring the Belief and Practice Dimensions}

In Islam, belief consists of two parts: one part, called "Basic Elements of Belief" includes six principle elements of belief: belief in God, in Angels, in Heavenly Books, in Prophets, in Fate and Divine Decree, and in the Hereafter, which define whether a person is a believer or not. The other part, called "Complementary Elements of belief" includes five other basic elements of belief: belief in Heaven and Hell, in the day of Judgment, in Resurrection, in enjoining the love of Prophet Mohammed, and in the Creation of the Universe.

Such dimension is hard to measure in a Muslim society, simply because it should apply to every Muslim, since every Muslim is supposed to possess the basic beliefs before he or she can even be considered a Muslim. So such undiscriminating factor may be hard to use as an indicator of religiosity because it is present in every one. It then becomes clear that the measurement of the construct of basic elements of belief poses a real problem for measurement and a great challenge for scale developers. First of all, it is difficult, and may be unjustifiable, to go about measuring religiosity among Muslims with out first assuring the presence of belief in Islam and its tenets. Additionally, it seems that it will be guaranteed that we get zero variation in items that measure this construct. Can we be justified in trying to measure Islamic religiosity or examine its presence or absence in individuals without looking at the most critical aspect of such religiosity, the basic belief aspect? And what advantage we have, in our attempt to assess religiosity, by including a dimension that will not distinguish between subjects, and thereby will not add any variation.

Another problem is in measuring the religious practice of individuals. A person may attend prayers in congregation for several reasons. For example, to avoid social isolation, to please his parents, or it can be a form of prestigious action to dominate over others. We cannot say that those who are high in religious practice are high in religiosity, because this practice could be routine action more than devotional.

\section{Offending Participants}

Another potential problem faced is the possibility of offending participants or provoking their sensitivity, particularly religious respondents, by the item content, especially when respondents are asked not to leave an unanswered questions. It may be hard for a religious person to be forced into making decisions regarding something about religion that the respondent does not have a clear idea about. More over, it is very difficult to ask some questions that some respondent consider as personal things between him and his God.

\section{Gender of Participants}

It seems to be difficult to have one single reliable scale that measures religiosity in both sexes. There are, for example, many issues that are good measures of religiosity, but apply only to men, for example, praying in mosque, wearing gold and silk, way of dressing and so on. The reverse is also true meaning that what is appropriate to ask women may not be so for men.

\section{Operationalization of Islamic Religiosity}


Creating a new dimension and especially in area like religion is not an easy task. This paper presents alternative construct for measuring Islamic religiosity in the context of Islamic countries and more specifically Jordan. Jordan is unique because Islam is the official religion and the followers belongs mostly to one ethnic group namely Arabs and other small ethnic groups which share the same religion and to some extent the same culture. We can argue that religion and ethnicity are intertwined in Jordan. The Jordanian with their Islamic belief intermingle with other groups who profess different religious belief.

The dimensions introduced in this study are directed more toward practical behavior. These dimensions are: Islamic financial services, seeking religious education, current Islamic issues, and sensitive products. The rationale behind selecting these dimensions is to encompass as many issues as possible so that the dimensions reflect the tenet that Islam is a complete way of life rather than as a bundle of rituals in the narrow religious sense.

\section{Islamic Financial Services.}

This dimension is composed from two parts; Islamic banking and insurance services. Banking was chosen because it is an important financial intermediary and vital institution in the economic. Muslim scholars consider Islamic banks as one of the most important steps in the process of Islamizing the economy. According to the Islamic religion, Muslims are not allowed to use the services offered by non-Islamic banks, which may contain some prohibited transactions according to Islamic law $(R i b a)$. The other part in this dimension is Islamic insurance, which is a relatively new enterprise. Insurance has been described as a device to cover losses when they occur by distributing them over a community or group. The importance of insurance in modern life can only be gauged by the fact that each and every facet of the normal activity of human life contains all types of risks and uncertainties.

This dimension includes 11 questions on different Islamic banking and insurance products. The response format on this question was on a 3 -point rank scale $(1=$ Not yet, $2=$ thinking about it, $3=$ already open account $)$. The first part include different Islamic banking products such as, Al-Wadiah (saving and current account), Al-Mudarabah (fixed account), purchase financing (car and house). The second part includes Islamic insurance products such as, Takaful (car), Family Takaful, family education Takaful, house fire Takaful, and medical Takaful.

\section{Seeking Religious Education}

This dimension is about how individuals try to increase their religious education. The emphasis here is not on education per se. Many studies show that education contributes little to explain variations in religiosity. In this dimension we tried to focus on different type of education which really can contribute to the religiosity of individuals, such as, attending religious talks at mosque, listening and watching religious programs, reading religious books and so on. The response format on this question was on a 3-point rank scale $(1=$ Never, $2=$ Sometimes, 3 = Most Frequent).

\section{Islamic Current Issue}

The third dimension is Islamic current issues. This concept of religion go along with our view that religion is a complete way of life rather than as a bundle of rituals in the narrow religious sense. According to this view, we tried to include in this dimension current Islamic issues, which influence the behavior of individuals. This dimension contains 20 different aspects of daily life issues of Muslim individual, such as the label of the food he buys, economy and currency speculation, implementation of Islamic law, apostate issue, preserving the Islamic manner in dressing, decline in the number of religious schools and prayers and so on. The purpose of this dimension is to measure the level of importance of such issues to the repondent. The response format on this question was on a 5 -point rank scale (ranging form $1=$ not important at all, to $5=$ the most important).

\section{Sensitive products}

The fourth dimension contains 13 statement related to consumption of different products that may contain doubtful items. Some of these items may or may not contain prohibited ingredients. Highly religious individuals are expected to be very doubtful to use these products. The response format on this question was on a 3-point rank scale $(1=$ Do Not Hesitate, $2=$ Little Doubt, $3=$ Very Doubtful $)$. All the four dimensions items are presented at Appendix 1.

\section{Data Collection}

Data for the present study were obtained form a survey of 1254 individuals, from whom 1101 useable questionnaires were obtained (a $87.7 \%$ response rate). The self-administered questionnaire was presented in 
Arabic since respondents speak only Arabic. A convenience sampling was used and the respondents were from the city of Amman. The data collection period was approximately five weeks. Table 3 presents the profile of the demographic characteristics of the total Sample.

\section{Data Analysis}

Data were analyzed using SPSS for Windows (version 17.0). As a preliminary step, religiosity items were factor analyzed to reduce the variables to a manageable number of components. Factoring ceased when all eigenvalues of greater than one were obtained and when a set of factors explaining a large percentage of the total variance was achieved. The principal component analysis and the ensuing varimax rotation produced eight factors that yielded eigenvalue greater than one. This was done to gain a clearer understanding of the underlying structure of these forty-nine items of religiosity. Overall, forty-one items loaded significantly (a item loading of at least $(0.50)$ on one of the eight factors). Reliability analysis was then carried out to examine the internal consistency of the factors obtained where Cronbach's alpha coefficient at 0.5 or higher was considered acceptable (Kerlinger \& Lee, 2000). Reliability test for the eight factors show that factor 8 is not highly reliable, so this factor was dropped. Loadings for these factors varied in a range between 0.53 and 0.88 . The first factor labeled as "Banking and insurance". The second factor labeled as "Public Islamic issues". While the third factor labeled as "Individual Islamic issues". The fourth factor labeled as "sensitive products". Regarding the fifth Factor it was labeled as "Food consumption" . Factor six" Religious education"and last factor "Ethics" covers the ethical behavior. The factors are exhibited in Table 4.

The basic issue addressed here is the appropriateness of the dimensions to be used as indicators of Islamic religiosity. The Correlation test was done among the seven factors extracted by factor analysis show that almost all factors are correlated with each other, while factor one, which consists of Islamic services dimension resulted with low correlation with other factors as exhibited in Table 5. This result indicates that the seven factors still can be used to measure the religiosity construct, but still we are looking for the most precise factors that provide us with high reliability and credibility. To achieve that reliability test was conduct as a auxiliary action.

The investigation of the religiosity scale is then pursued by assessing the reliability of the scale in order to check for its internal consistency. Cronbach alpha coefficient will be used in testing the consistency of different items used in this research. The results indicated three factors with Cronbach's alpha coefficient at 0.5 or higher. The total Cronbach alpha for the three factors as shown in Table 6. is 0.86 . This means that three factors among the seven factors are the best factors to be used in measurement the religiosity construct in Islamic context.

Compared to previous studies that explored the dimensions of religiosity, it is noted that our study provides a very good reliability result. Some examples of these studies are:

- Sood and Nasu (1995) Cronbach alpha coefficient ranged from 0.79 to 0.82 for the American Protestant respondents and 0.59 to 0.65 for the Japanese respondents.

- Guinee and Tracy (1997) obtained Cronbach alpha of 0.97.

- Barnett et al (1996) Cronbach alpha coefficient ranged from 0.79 to 0.96.

- Delener (1992) obtained Cronbach alpha of 0.84.

\section{Conclusions}

The main purpose of this study was to investigate different methods used in the measurement of religiosity. The present study has provided some new information that adds to our current limited stock of knowledge concerning the measurement of religiosity in the area of consumer behavior research. The general findings of the current studies, combined with the examination of the relevant literature, support the suggestion that religiosity is multidimensional. The result shows that three dimensions (seeking religious education, Islamic current issue, and sensitive products) yield the best combination of dimensions to measure Islamic religiosity. Although the scale is tentative and conducted in new environment and away form western context, the general results support the assumption of dimensionality in the measurement of Islamic religiosity. It could also be concluded that the nature of religiosity, Islam in this case, is a profoundly complex construct to measure. In addition, the way of approaching the problem of measuring religiosity is another delicate issue. This research helped highlight some problems and obstacles in the road to measuring religiosity among Muslims. This research may be considered as a first step in scale development to understand more deeply one of the factors that influence the consumer behavior.

While there is no consensus in the literature, regarding the exact number of religiosity dimensions. The study utilized a multi-item scale covering cognitive and behavioral aspects of religiosity in order to obtain a clear 
picture of how religious the subjects really are. As the result of factor analysis, correlation, and reliability, religiosity could be represented by three religious dimensions namely religious education, sensitive products and current issues, which represents both cognitive and behavioral dimension of religiosity.

This inventory in the current research has proved to be a reliable measure since a high alpha coefficient of 0.86 was obtained for the scale. The reliability tests performed on the three components of the scale also showed a high degree of internal consistency with alpha coefficients range from of 0.57 to 0.86 respectively. Although a higher alpha level would be preferred for religiosity, the scale is generally acceptable for an initial research effort. This scale was used in the current study to measure the degree of religiosity of a group which had not previously been measured using this scale. Finally, the measurement provided in this article should be not treated as conclusive. It is possible that using these dimensions in other Muslim country would produce different results. In considering the results of the current study, one should recognize the inherent limitations associated with generalizing these findings beyond the geographic area where the sample was collected, since other countries have its own unique characteristics.

\section{References}

Alan, K.M. (2000). Attitudes toward church advertising in Hong Kong. Marketing Intelligence and Planning, 18(1), 39-44.

Albehairi, A., and Demerdash, A. (1988). Religious orientation Scale. $2^{\text {nd }}$ edition. Cairo, Egypt.

Albelaikhi, A. A. (1988). Religious Orientation and Fear of Death among Muslim and Christian Individuals. University of Rhode Island, Psychology Department, Kingston.

Albelaikhi, A. A. (1997). Development of a Muslim Religiosity Scale. Unpublished PhD thesis, University of Rhode Island.

Allport, G. W., and Ross, J.M. (1967). Personal Religious Orientation and Prejudice. Journal of Personality and Social Psychology, 5, 432-443.

Alsanie, S. I. (1989). Relationship between level of Religiosity and Criminal Behavior. Unpublished Doctoral Dissertation, Imam Ibn Suad Islamic University, Saudi Arabia.

Bergin, A. E. (1991). Values and religious issues in psychotherapy and mental health. American Psychologist, 46, 394-403.

Cutler, B. D. (1991). Religion and marketing: Important research area or a footnote in the literature. Journal of Professional Services Marketing, 8, 153-164.

Delener, N. (1990a). The Effects of Religious Factors on Perceived Risk In Durable Goods. Journal of Consumer Marketing, 7(3) 27.

Delener, N. (1990b). An examination of the religious influences as predictors of consumer innovativeness. Journal of Midwest Marketing, 5, 167-178.

Delener, N. (1994). Religious contrasts in consumer decision behaviour patterns: Their dimensions and marketing implications. European Journal of Marketing, 28, 36-53.

Delener, N., \& Schiffman, L. G. (1988). Family decision making: The impact of religious factors. In G. Frazier, C.

Essoo, N., \& Dibb, S. (2004). Religious influences on shopping behavior: An exploratory study. Journal of Marketing Management, 20, 683-712.

Faulkner, J. E., \& DeJong, D. (1966). Religiosity in 5-D: An Empirical Analysis. Social Forces 45(December): 246-54

Fishbein, M., and Ajzen, I. (1974). Attitudes toward objects as predictors of single and multiple behavioral criteria. Psychological Review, 81, 59-74.

Fukuyama, Y. (1961). The Major Dimensions of Church Membership. Review of Religious Research 2 (summer): $154-61$

Genia, V. (1993). A psychometric evaluation of the Allport-Ross I/E scales in a religiously heterogeneous sample. Journal of the Scientific Study of Religion, 32(3), 284-290.

Glock, C. (1962). On the Study of the Religious Commitment. Research Supplement of Religious Education (July/August): 98-110. 
Glock, C. Y. (1959). The Sociology of Religion. pp. 153-177 in Robert Merton et al., (eds.), Sociology Today. New York: Basic books.

Glock, C. Y., \& Rodney, S. (1965). Religion and Society in Tension. Chicago: Rand McNally

Gorsuch, R. L. (1984). The Boon and Bane in of investigation Religion. American Psychologist, 39, 228-236.

Guthrie, S. (1980). A Cognitive Theory of Religion. Current Anthropology,(21) 2, April.

Hawkins, D. I., Best, R. J., and Coney, K. A. (2001). Consumer Behavior: Building Marketing Strategy. $6^{\text {th }}$ edition. Published by Irwin McGraw-Hill.

Hirschman, E. C. (1983). Religious Affiliation and Consumption Process: An Initial Paradigm. Journal of Research in Marketing, 6: 131-170.

Kim, S. F., David, S. W., and Zafer, B. E. (2004). The influence of religion on attitudes towards the advertising of controversial products. European Journal of Marketing Vol. 38 No. 5/6, pp. 537-555.

King, M., and Hunt, R. (1969). Measuring the religious variable: Amended findings. Journal for the Scientific Study of Religion 8:321-323.

King, M., and Hunt, R. (1972). Measuring the Religious Variables: Replication. Journal of the Scientific Study of Religion 11(Sept): 240-251

Lenski, G. (1961). The Religious Factor. New York, Doubleday.

Mcdaniel, S. W., \& Burnett, J. J. (1990). Consumer Religiosity and Retail Store Evaluative Criteria. Journal of The Academy of Marketing Science, (Spring) 18(2), 101.

Mcfarland, S. (1984). Psychology of Religion: A call for a broader paradigm. American Psychologist. 39, 321-324.

Safiek, M. (2009). Relevancy and Measurement of Religiosity in Consumer Behavior Research. International Business Research. Vol. 2. No. 2, pp. 75-84.

Sleek, S. (1994). Spiritual Problems included DSM-IV. The Mintor, 25 (6), p.8.

Sood, J., and Nasu Y. (1995). Religiosity and Nationality: An Exploratory Study of their effects on Consumer Behavior in Japan and The United States. Journal of Business Research 34, 1-9.

Starck, R., and Charles G. (1968). American Peity: The Nature of Religious Commitment. Berkely: University of California Press.

Stark, N., and Finke, D. (2002). Beyond Church and Sect: Dynamics and Stability in Religious Economies. In Sacred Markets, Sacred Canopies: Essays on Religious Markets and Religious Pluralism, edited by Ted Jelen, 31-62. Lanham, MD: Rowman \& Littlefield Publishers,

Taai, N. M. (1985). Religious Behavior Scale._Kuwait: Arrobyaan Publishing.

Wilkes, R., Burnett J., \& Howell, R. D. (1986). On the Meaning and Measurement of Religiosity in Consumer Research. Journal of the Academy of Marketing Science (14): 47-56

Table 1. Measures of Religiosity in Consumer Research

\begin{tabular}{|l|c|l|}
\hline Author and Year & No. of Dimensions & Name of Dimensions \\
\hline Allport and Ross (1967) & 2 & $\begin{array}{l}\text {-Intrinsic } \\
\text {-Extrinsic }\end{array}$ \\
\hline Hirschman (1981) & 1 & Religious Affiliation \\
\hline Wilkes et al. (1986) & 4 & $\begin{array}{l}\text {-church Attendance } \\
\text {-importance of religious values } \\
\text {-confidence in religious values } \\
\text {-self-perceived religiousness }\end{array}$ \\
\hline Delener (1990) & 3 & $\begin{array}{l}\text {-religious affiliation, } \\
\text {-perceived strength of religious affiliation } \\
\text {-religious orientation }\end{array}$ \\
\hline McDaniel and Burnett (1990) & 2 & $\begin{array}{l}\text {-religious affiliation, } \\
\text {-religious commitment }\end{array}$ \\
\hline Sood and Nasu (1995) & 4 & $\begin{array}{l}\text {-personal activity in one's religion } \\
\text {-importance and confidence in religious values. } \\
\text {-Belief in the basic tenets of one's religion } \\
\text {-self-evaluation of one's religiosity } \\
\text {-religious Affiliation }\end{array}$ \\
\hline Alan K.M. Au (2000) & & $\begin{array}{l}\text {-religious affiliation } \\
\text {-self-evaluation of one's religiosity }\end{array}$ \\
\hline Kim et al., (2004) & 2 & $\begin{array}{l}\text {-religious affiliation, } \\
\text {-religious commitment }\end{array}$ \\
\hline Mokhlis (2009) & 2 &
\end{tabular}

Source: Authors collection. 
Table 2. Measures of Islamic Religiosity

\begin{tabular}{|l|c|l|}
\hline \multicolumn{1}{|c|}{ Authors (Year) } & $\begin{array}{c}\text { Number of } \\
\text { Dimensions }\end{array}$ & \multicolumn{1}{|c|}{ Name of Dimensions } \\
\hline Taai (1985) & 2 & Beliefs and Practices \\
Albehairi and Demerdash (1988) & 2 & Intrinsic and extrinsic religiosity \\
Alsanie (1989) & 1 & Unidimensional approach.(Belief and practice) \\
Albliakhi (1997) & 3 & Belief, attitudes, and practice. \\
\hline
\end{tabular}

Source: Author collection.

Table 3. Profile of Demographic Characteristics of the total Sample

\begin{tabular}{|c|c|c|c|}
\hline Personal Demographic Characteristics & Male & Female & Total \\
\hline Gender & $\begin{array}{l}535 \\
(48.6 \%)\end{array}$ & $\begin{array}{l}566 \\
(51.4 \%)\end{array}$ & $\begin{array}{l}1101 \\
(100 \%)\end{array}$ \\
\hline \multicolumn{4}{|l|}{ Marital Status: } \\
\hline Single & $\begin{array}{l}248 \\
(44.0 \%)\end{array}$ & $\begin{array}{l}316 \\
(56.0 \%)\end{array}$ & $\begin{array}{l}564 \\
(51.3 \%)\end{array}$ \\
\hline \multirow[t]{2}{*}{ Married } & 277 & 240 & 517 \\
\hline & $(53.6 \%)$ & $(46.4 \%)$ & $(47.0 \%)$ \\
\hline Divorced & $\begin{array}{l}10 \\
(0.9)\end{array}$ & $\begin{array}{l}8 \\
(0.7 \%)\end{array}$ & $\begin{array}{l}18 \\
(1.6 \%)\end{array}$ \\
\hline \multicolumn{4}{|l|}{ Age (Years): } \\
\hline$<20$ & $\begin{array}{l}28 \\
(43.8 \%)\end{array}$ & $\begin{array}{l}36 \\
(56.3 \%)\end{array}$ & $\begin{array}{l}64 \\
(5.8 \%)\end{array}$ \\
\hline \multirow[t]{2}{*}{$21-30$} & 266 & 358 & 624 \\
\hline & $(42.6 \%)$ & $(57.4 \%)$ & $(56.8 \%)$ \\
\hline \multirow[t]{2}{*}{$31-40$} & 132 & 92 & 224 \\
\hline & $(58.9 \%)$ & $(41.1 \%)$ & $(20.4 \%)$ \\
\hline \multirow[t]{2}{*}{$>40$} & 108 & 78 & 186 \\
\hline & $(9.8 \%)$ & $(7.1 \%)$ & $(16.9 \%)$ \\
\hline \multicolumn{4}{|l|}{ Education: } \\
\hline \multirow[t]{2}{*}{ Diploma } & 115 & 42 & 157 \\
\hline & (21.4) & $(7.5)$ & $(14.2)$ \\
\hline \multirow[t]{2}{*}{ First Degree } & 336 & 389 & 725 \\
\hline & $(62.8)$ & $(68.7)$ & $(65.8)$ \\
\hline \multirow[t]{2}{*}{ Postgraduate } & 84 & 135 & 219 \\
\hline & $(15.8)$ & $(23.8)$ & $(19.8)$ \\
\hline \multicolumn{4}{|l|}{ Income } \\
\hline \multirow[t]{2}{*}{ High } & 78 & 32 & 110 \\
\hline & $(14.5)$ & $(5.6)$ & $(9.9)$ \\
\hline \multirow[t]{2}{*}{ Middle } & 388 & 352 & 740 \\
\hline & $(72.5)$ & $(62.1)$ & $(67.2)$ \\
\hline \multirow[t]{2}{*}{ Low } & 69 & 182 & 251 \\
\hline & (12.8) & $(32.1)$ & $(22.7)$ \\
\hline
\end{tabular}

Note: Number in (\%) represents the percentage 
Table 4. Factor Structure of Islamic Religiosity

\begin{tabular}{|c|c|c|}
\hline Factor Composition & $\begin{array}{l}\text { Factor } \\
\text { Loadings }\end{array}$ & $\begin{array}{l}\text { Eigen } \\
\text { Value }\end{array}$ \\
\hline \multicolumn{3}{|l|}{ Factor 1: Islamic Financial Services } \\
\hline 1. Current account (Al-Wadiah) & 0.521 & \\
\hline 2. Fixed account (Mudarabah) & 0.557 & \\
\hline 3. Business financing & 0.563 & \\
\hline 4. Purchase financing (House) & 0.711 & \\
\hline 5. Purchase financing (Car) & 0.709 & 5.32 \\
\hline 6. Takaful-Car & 0.656 & \\
\hline 7. Family Takaful & 0.749 & \\
\hline 8. Family education Takaful & 0.742 & \\
\hline 9. House fire Takaful & 0.753 & \\
\hline 10. Medical Takaful & 0.711 & \\
\hline \multicolumn{3}{|l|}{ Factor 2: Public Islamic issues } \\
\hline 1. Aurat covered clothing. & 0.687 & \\
\hline 2. Those who are eligible, reluctant to pay zakat. & 0.691 & \\
\hline 3. Decreasing numbers of Muslim congregating at mosques. & 0.648 & \\
\hline 4. Muslim economy level. & 0.717 & 6.98 \\
\hline 5. The implementation of Syariah Law. & 0.748 & \\
\hline 6. Drugs issue (Heroin Addiction). & 0.705 & \\
\hline 7. Religious school shortage & 0.721 & \\
\hline 8. Muslim participation in the industrial sector & 0.556 & \\
\hline \multicolumn{3}{|l|}{ Factor 3: Individual Islamic Issues } \\
\hline Muslim man wearing silk clothing & 0.884 & \\
\hline Muslim man wearing gold accessories & 0.886 & \\
\hline Forbidding liquor sales & 0.867 & \\
\hline Forbidding currency speculations & 0.550 & \\
\hline Licensing enjoyment centers for both sex (Disco) & 0.820 & \\
\hline Women using perfume & 0.750 & \\
\hline \multicolumn{3}{|l|}{ Factor 4: Sensitive products } \\
\hline 1. Toiletries (tooth paste/hair shampoo) & 0.634 & \\
\hline 2. Mixed flour (for baking, bread, pastry, pudding) & 0.631 & \\
\hline 3. traditional medicine & 0.534 & 3.32 \\
\hline 4. Perfume/deodorant & 0.702 & \\
\hline 5. Skin care (cleanser, toner, moisturizer, night cream) & 0.703 & \\
\hline 6. Cosmetics (lipstick; lip gloss) & 0.785 & \\
\hline \multicolumn{3}{|l|}{ Factor 5: Food Consumption } \\
\hline 1. Imported halal meat & 0.659 & \\
\hline 2. Local canned/boxed food & 0.750 & 1.68 \\
\hline 3. Imported canned/boxed food & 0.749 & \\
\hline \multicolumn{3}{|l|}{ Factor 6: Religious Education } \\
\hline Attending religious talk at mosque. & 0.550 & \\
\hline Reading religious books and magazines individually & 0.535 & 1.27 \\
\hline listening to the religious programs broadcasted by local radio station & 0.703 & \\
\hline Watching religious programs on TV & 0.700 & \\
\hline \multicolumn{3}{|l|}{ Factor 7: Ethics } \\
\hline 1) Cheating on the weighing scales. & 0.710 & 1.61 \\
\hline 2) Humiliation towards Muslim & 0.695 & \\
\hline
\end{tabular}

Cumulative variance explained by seven factors: $60 . \%$

Extraction Method: principal Component Analysis

Rotation Method: Varimax with Kaiser Normalization. 
Table 5. Correlation among the Factors

\begin{tabular}{|c|c|c|c|c|c|c|c|c|}
\hline & & Factor1 & Factor2 & Factor3 & Factor4 & Factor5 & Factor6 & Factor7 \\
\hline Pearson & Factor1 & 1.000 & -0.32 & -.005 & .030 & $.080 * *$ & $.111 *$ & $-.082 * *$ \\
\hline \multirow[t]{6}{*}{ Correlation } & Factor2 & -.032 & 1.000 & $.223 *$ & $.197 *$ & $.209 * *$ & $.350 *$ & $.350 *$ \\
\hline & Factor3 & -.005 & $.223 * *$ & 1.000 & $.117^{*}$ & $.087 * *$ & $.105 *$ & $.289 *$ \\
\hline & Factor4 & .030 & $.197 * *$ & $.117 *$ & 1.000 & $.429 * *$ & $.139 *$ & $.072 *$ \\
\hline & Factor5 & $.080 * *$ & $.209 * *$ & $.087 *$ & $.429 *$ & 1.000 & $.179 *$ & $.101^{*}$ \\
\hline & Factor6 & $.111^{* *}$ & $.350 * *$ & $.105 *$ & $.139 *$ & $.179 * *$ & 1.000 & $.154^{*}$ \\
\hline & Factor7 & $-.082 * *$ & $.350 * *$ & $.289 *$ & .072 & $.101 * *$ & $.154 *$ & 1.000 \\
\hline \multirow{7}{*}{$\begin{array}{l}\text { Sig. } \\
\text { (2-tailed) }\end{array}$} & Factor 1 & . & .298 & .884 & .341 & .010 & .000 & .008 \\
\hline & Factor2 & .298 & $\cdot$ & .000 & .000 & .000 & .000 & .000 \\
\hline & Factor3 & .884 & .000 & & .000 & .004 & .000 & .000 \\
\hline & Factor4 & .341 & .000 & .000 & & .000 & .000 & .018 \\
\hline & Factor5 & .010 & .000 & .004 & .000 & & .000 & .001 \\
\hline & Factor6 & .000 & .000 & .000 & .000 & .000 & & .000 \\
\hline & Factor7 & .008 & .000 & .000 & .018 & .001 & .000 & \\
\hline \multirow[t]{7}{*}{$\mathrm{N}$} & Factor1 & 1050 & 1040 & 1039 & 1037 & 1045 & 1047 & 1045 \\
\hline & Factor2 & 1040 & 1108 & 1096 & 1094 & 1102 & 1104 & 1103 \\
\hline & Factor3 & 1039 & 1096 & 1106 & 1092 & 1100 & 1102 & 1101 \\
\hline & Factor4 & 1037 & 1094 & 1092 & 1106 & 1101 & 1102 & 1101 \\
\hline & Factor5 & 1045 & 1102 & 1100 & 1101 & 1114 & 1110 & 1119 \\
\hline & Factor6 & 1047 & 1104 & 1102 & 1102 & 1110 & 1116 & 1111 \\
\hline & Factor7 & 1045 & 1103 & 1101 & 1101 & 1109 & 1111 & 1115 \\
\hline
\end{tabular}

Table 6. Summary of reliability test for Religiosity dimensions

\begin{tabular}{|l|c|c|}
\hline \multicolumn{1}{|c|}{ Religiosity Dimensions } & $\begin{array}{c}\text { No. of } \\
\text { Items }\end{array}$ & $\begin{array}{c}\text { Reliability Coefficient } \\
\text { (Cronbach Alpha) }\end{array}$ \\
\hline Islamic Financial Services & 10 & 0.4655 \\
Religious Education & 4 & 0.5749 \\
Sensitive Products & 13 & 0.8141 \\
Current Issues & 20 & 0.8605 \\
\hline Total reliability for all items & 47 & 0.8654 \\
\hline
\end{tabular}




\section{Appendix 1: Questionnaire}

\section{Section A}

Please answer the questions below by placing a check mark " $\sqrt{ }$ " in the appropriate boxes or, where applicable, by writing your response in the space provided:
1. Gender
2. Marital status
3. Level of education:
4. Age:
( $\quad$ ) Less than JD 1000
( $\quad$ JD1001 - JD 3000
More than JD3000

Male ( )

Single ( )

Diploma ( )

Female $(\quad)$
Married $(\quad)$
First degree $(\quad)$

Divorced ( )

Less than 20(

21-30( )

Postgraduate ( )

5. Please indicate your total household income:

31- $40(\quad) \quad$ More than $40(\quad)$

Section - B

\section{RELIGIOUS EDUCATION}

Several methods can be used to broaden our religious knowledge. What are the methods you frequently use for this purpose. Please tick your answer according to the 3 -point scale $(1=$ Never; $2=$ Sometimes; $3=$ Most frequent) :

\section{Method}

a. Attending religious talk at mosque/other

Muslim praying places.

\section{Never Sometimes}

Most

b. Reading religious books and magazines individually 1

c. Listening to the religious programs broadcasted by local radio station

d. Joining tabligh/usrah groups

e. Watching religious programs on T.V

\section{CURRENT ISSUES}

What is your opinion towards the situations below. Please give your answer using the 5 -point scale $(1=$ Not important at all; $2=$ Not important; $3=$ Not sure; $4=$ Very important; $5=$ The most important):

a. The validity of $H A L A L$ mark used by

$\begin{array}{cc}\text { Not } & \text { The Most } \\ \text { important } & \text { important }\end{array}$
non- Muslim food operators.

b. Cheating on the weighing scales.

c. Humiliation towards Muslim

d. Aurat covered clothing.

$1 \quad 3$

123

e. Those who are eligible, reluctant to pay zakat. 1

f. Decreasing numbers of Muslim congregating at mosques.

g. Muslim economy status.

h. The implementation of Syariah Law.

i. Apostate issue.

j. Religious school shortage

k. Muslim man wearing silk clothing

1. Muslim man wearing gold accessories

m. Forbidding liquor sales

n. Forbidding currency speculations important

o. The premise non-Muslim praying idol on the business area

$\begin{array}{llll}1 & 23 & 4 & 5 \\ 1 & 23 & 4 & 5 \\ 1 & 23 & 4 & 5 \\ 1 & 23 & 4 & 5 \\ 1 & 23 & 4 & 5 \\ 1 & 23 & 4 & 5 \\ 1 & 23 & 4 & 5 \\ 1 & 23 & 4 & 5 \\ 1 & 23 & 4 & 5 \\ 1 & 23 & 4 & 5 \\ 1 & 23 & 4 & 5 \\ 1 & 23 & 4 & 5 \\ 1 & 23 & 4 & 5 \\ 1 & 23 & 4 & 5 \\ & & & \\ 1 & 23 & 4 & 5 \\ 1 & 23 & 4 & 5 \\ 1 & 23 & 4 & 5 \\ 1 & 23 & 4 & 5 \\ 1 & 23 & 4 & 5\end{array}$




\section{t. Selling condoms/family planning pills $\quad \begin{array}{lllll}1 & 23 & 4 & 5\end{array}$}

\section{PRODUCTS WITH SENSITIVE ELEMENTS}

Please tick your level of hesitation when buying these products. The answer is based on the 3-point scale: 1=do not hesitate; $2=$ little doubt; $3=$ very doubtful.
a. leather based goods (e.g., shoes, belt, etc)
b. food prepared by non-Muslim cook
c. Imported halal meat
d. Local canned/boxed food even though they have HALAL mark
e. Imported canned/boxed food even though they have HALAL mark
12
12
1
3
Canned food without expiry date

1
g. Toiletries (tooth paste/soap/hair shampoo)
h. Mixed flour (for baking, bread, pastry, pudding)
i. Modern medicine
j. Traditional medicine
k. Perfume/deodorant
1. Skin care (cleanser, toner, moisturizer, night cream)
m. Cosmetics (lipstick; lip gloss)

Little Very

Hesitate

Doubt

Doubtful

ISLAMIC FINANCIAL SERVICES

What is your opinion towards the Islamic financial services below? Please give your answer using the 3-point scale $1=$ Not yet, 2 = thinking about it, 3 = already open account
a. Current account (Al-Wadiah)
b. Fixed account (Mudarabah)
c. Business financing
d. Purchase financing (House)
e. Purchase financing (Car)
f. Takaful - Car
g. Family Takaful
h. Family education Takaful
i. House fire Takaful
j. Medical Takaful

$\begin{array}{lll}1 & 2 & 3 \\ 1 & 2 & 3 \\ 1 & 2 & 3 \\ 1 & 2 & 3 \\ 1 & 2 & 3 \\ 1 & 2 & 3 \\ 1 & 2 & 3 \\ 1 & 2 & 3 \\ 1 & 2 & 3 \\ 1 & 2 & 3\end{array}$

